\title{
Perkütan endoskopik gastrostomide hipergranülasyon dokusu bakımına farklı bir bakış: Olgu sunumu ve literatürün gözden geçirilmesi
}

\author{
A different perspective of hypergranulation tissue care in percutaneous endoscopic gastrostomy: A \\ case report and review of the literature
}

\section{(D) Güldan KAHVECI ${ }^{1}$, (D) Selma DAĞCI ${ }^{2}$, (D) Roni ATALAY ${ }^{3}$}

Umraniye Eğitim ve Araştırma Hastanesi, ${ }^{1}$ Nutrisyon Hemşireliği Bölümü, Istanbul

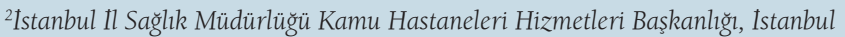

Ankara Şehir Hastanesi, ${ }^{3}$ Gastroenteroloji Kliniği, Ankara

Perkütan endoskopik gastrostomi, çeşitli nedenlerle ağı yoluyla beslenemeyen hastalarda beslenme süresi 4-6 haftadan uzun sürecek ise endoskopik olarak karın duvarından girilerek mideye tüp yerleştirme işlemidir. Yatak başında işlemin yapılabilmesi ve düşük maliyetli olması nedeniyle sıklıkla tercih edilmektedir. Perkütan endoskopik gastrostomi tüpü yerleştirme sonrasinda minör ve majör komplikasyonlar gelișebilmektedir. Minör komplikasyonlar arasında yer alan hiperganülasyon doku gelişimi tedavi edilmezse enfeksiyona, enfeksiyon tedavi edilmez ise nekrotizan fasiite neden olabilmekte ve nadir de olsa ölümle sonuçlanabilmektedir. Hastaların beslenmesinin kesintiye uğramaması için komplikasyonların önlenmesi büyük önem taşımaktadır. Olgu sunumumuzda perkütan endoskopik gastrostomi tüpünün giriş yerinde oluşan komplikasyonlar bildirilmiş, olası nedenleri tartışılmiş, minör komplikasyonlar arasında yer alan hipergranülasyon dokusunun bakımı \% 10 povidon iyot solüsyonu (batikon, betadin) ile yapılmış bir vaka sunulmuş ve konu ile ilgili literatür derlenmiştir.

Anahtar kelimeler: Bakım, hipergranülasyon dokusu, \%10 povidon iyot solüsyonu, batikon

\section{GIIRIS}

Perkütan endoskopik gastrostomi (PEG), ağız yoluyla beslenemeyen gastrointestinal sistem fonksiyonları normal olan, prognozu uzun süreli hastalara enteral beslenme desteği sağlamak amacı ile karın duvarından mideye direkt girilerek tüp yerleștirilmesi işlemidir (1). PEG ilk kez Gauderer ve Ponsky tarafından 1980 yılında uygulanmıştır (2). PEG tüpünün yerleştirilmesi sırasında ve yerleştirildikten sonra görülen komplikasyonlar minör ve majör komplikasyonlar olmak üzere iki gruba ayrılmaktadır (3). Minör komplikasyonlar \%8-30, majör komplikasyonlar ise \%1-4 oranında görülmektedir. Majör komplikasyonlar; pulmoner aspirasyon, peritonit, perforasyon, hemoraji, gastrokolokütanöz fistüller ve nekrotizan fasiit, en sık görülen minör komplikasyonlar ise; periostomal enfeksiyon, tüpün tıkanması, buried bumper sendromudur. Periostomal enfeksiyonlar vakaların yaklaşık \%15'inde görülmektedir. Bu enfeksiyonlarm nedenleri arasinda diyabetus mellitus, malnütrisyon, yanlış pansuman tekniği ve vücudun PEG tüpünü yabancı cisim olarak algılaması sonucu oluşan direnajlı lokal hipergranülasyon dokusu yer almaktadır. Hipergranülasyon dokusu PEG tüpünün giriş yerinde genellikle
Percutaneous endoscopic gastrostomy is the procedure of inserting a tube into the stomach by endoscopically entering the abdominal wall; this technique is used for patients who cannot be fed orally for longer than 4-6 weeks for various reasons. The procedure is often preferred because it can be performed at the bedside and is cost-effective. Minor and major complications may occur after percutaneous endoscopic gastrostomy tube placement. Hypergranulation tissue, which is one of its minor complications, can cause an infection that can lead to necrotizing fasciitis if the infection is left untreated and may rarely result in death. Prevention of complications is of paramount importance in order not to interrupt the feeding of the patients. This case report discussed percutaneous endoscopic gastrostomy tube complications and their possible causes and hypergranulation tissue care which was done using a 10\% povidone-iodine solution (Batikon and Betadine). It also included a literature review.

Keywords: Care, hypergranulation tissue, $10 \%$ povidone iodine solution, the baticon

en sık görülen komplikasyondur. Hipergranülasyon dokusu tedavisinde literatürde, topikal antimikrobiyal ve düşük doz steroid içeren pomadların kullanımı ile gümüş nitrat çubuklarıyla koterizasyon uygulanması bulunmaktadır. Bu tedavi seçeneklerinin hiçbirinin diğerlerinden daha etkili olduğu kanıtlanmamıştır (4-6).

Bu sunumda PEG tüpünün giriş yerinde oluşan hipergranülasyon dokusunun tedavisinde $\% 10$ povidon iyot solüsyon kullanımının etkili olduğu olguyu sunarak, bu patolojik sürecin tedavisine literatür taramasının da desteğiyle ışı tutmayı amaçladik.

\section{OLGU SUNUMU}

Otuzsekiz yaşında, erkek, evli ve bilinen herhangi bir sağlık problemi olmayan hasta I.E. araç dışı trafik kazası sonucu kranial kanama teşhisi ile üç ay anestezi ve reaminasyon ünitesinde takip edilmiştir. Yatışından altı hafta sonra PEG tüpü açılmıştır. Anestezi ve reanimasyon ünitesinden eksterne edilen; yatağa bağımlı, trakeostomili ve PEG tüpü olan hastanın 
palyatif bakım ünitesinde takiplerine devam edilmektedir. Palyatif bakım ünitesinde takibinin onuncu gününde PEG tüpünün giriş yerinde hipergranülasyon dokusu ve akıntısı gelişmiştir. Hipergranülasyon dokusu palyatif hemşiresi tarafindan tespit edilip nütrisyon destek ekibine haber verilmiştir. Uzman görüşü alınarak hastada oluşan hipergranülasyon dokusu günlük, PEG tüpünün giriş yeri \%10 povidon iyot solüsyonu ile iki kez silinerek kurulandıktan sonra açık bırakılarak bakımı yapılmıştır. 1 hafta sonra hipergranülasyon dokusunda küçülme olmuş ve on beş gün sonrasında tamamiyla ortadan kalkmıştır.

\section{TARTIŞMA}

Gastrostomi tüpünün giriş yerinde hipergranülasyon dokusu gelişimi, PEG tüpü olan hastalarda sık görülen bir komplikasyondur (5). PEG tüpünün giriş yerinde vücudun yabancı bir maddeye tepkisi sonucu hipergranülasyon dokusu oluşabilir (7). Her ne kadar granülasyon oluşumunun tam mekanizması tarif edilmemiş olsa da, granülasyon oluşumunun yaygın bir nedeni, dış sabitleme plakasının tüpün serbestçe hareket etmesine izin verebilecek şekilde yanlış konumlandırılmasıdır. Bu hareket bölgedeki sürtünmeye neden olur ve granülasyon dokusu üretimini başlatır (8). Aynı zamanda kötü bir şekilde tutturulmuş bir tüpten sızıntı nedeniyle aşırı nem gibi etkenin çıkış bölgesinde cilt bozulmasına neden olan faktör de sorumlu görünmektedir (5).

Granülasyon dokusu vaskülerdir, kolayca kanar (7), çirkin görünümdedir, enfeksiyon riski taşır. Aynı zamanda cildin ağrımasına neden olan eksüda üretebilir. Dış sabitleme plakasının doğru konumda olup olmadığını ve hasta ve/veya bakıcıların doğru konumu bilmesi önemlidir. Cildi hipergranülasyon dokusundan gelebilecek herhangi bir eksüdadan korumak için bir bariyer kremi kullanılabilir. PEG tüpünün günlük olarak temizlenmesi ve kapatılması, eksüdanın miktarına bağlı olacaktır. Bir enfeksiyon şüphesi varsa antimikrobiyal ajanlar ile pansuman kullanılmasını önerilmektedir. Tüm bu önlemlere rağmen geçmiyorsa literatürde, topikal antimikrobiyal ve düşük doz steroid içeren pomadların kullanımı ile gümüş nitrat çubukları ile koterizasyon uygulanmasında tedavi seçenekleri açıklanmış olmakla birlikte, hiçbirinin diğerlerinden daha etkili olduğu kanıtlanmamıştır $(5,6,9,10)$. Ülkemizde gastrostomi bakımında kullanılan ürünler (\%10 povidon iyot solüsyon, sabunlu su, serum fizyolojik) bakımindan sağlık kurumları arasında farklılıklar görülebilmektedir. Literatür taramasında PEG tüpü bakımı için gereken sarf malzemeleri, steril olmayan 4x4 gazlı bez, non-steril eldiven ve pH 5.5 olan yumuşak sabun oluşturmaktadır. PEG tüpü çevresindeki cilt steril değildir ve steril bir prosedür gerektirmez. Bu nedenle steril eldivenlere ve diğer malzemelere ihtiyaç duyulmaz. PEG tüpünün etrafında herhangi bir komplikasyon bulunmadığı zaman pansuman; yumuşak sabun, su ve bölgede uzun süreli bir enflamatuar yanıta yol açabilecek elyaf bırakma riski düşük olan tek kullanımlık bir gazlı bez kullanılarak gerçekleştirilir. Bölge temizledikten sonra, alanın tamamen kuru olduğundan emin olmak önemlidir. Cildin tahriş olması ve yumuşamasına neden olarak yüzeysel cilt enfeksiyonuna yol açabileceği için tüp çevresinde krem ve pudra kullanımından kaçınılmalıdır.

PEG tüpünün ilk pansumanı işlem sonrası günden itibaren ilk yedi gün, günlük olarak yapılmalıdır $(6,9,12)$. Olgumuzda yoğun bakım ünitesinde PEG tüpü bakımı günlük olarak

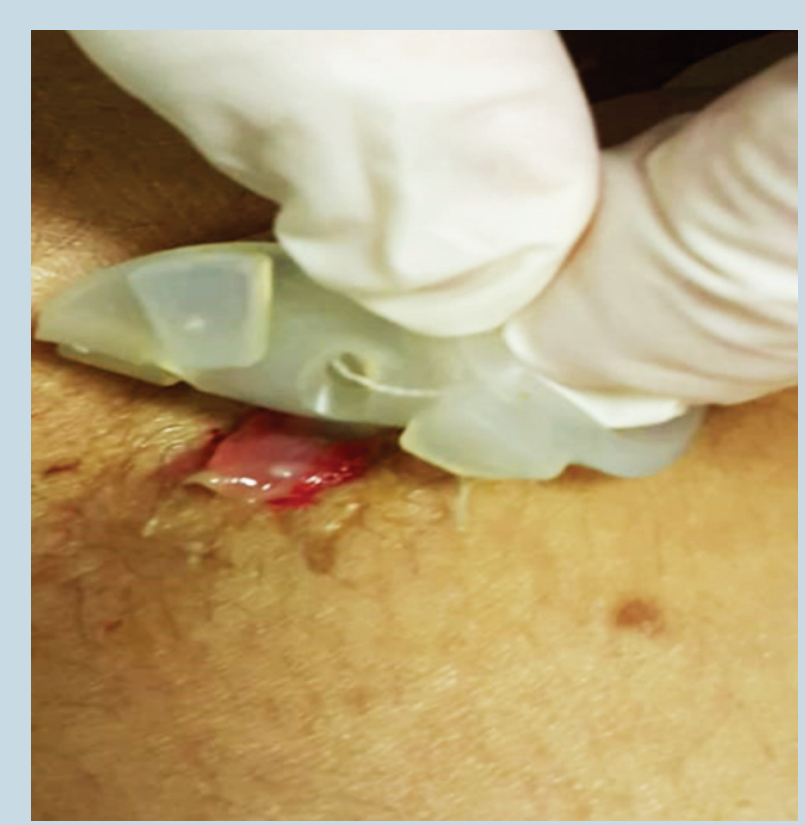

Resim 1. Hipergranülasyon dokusu

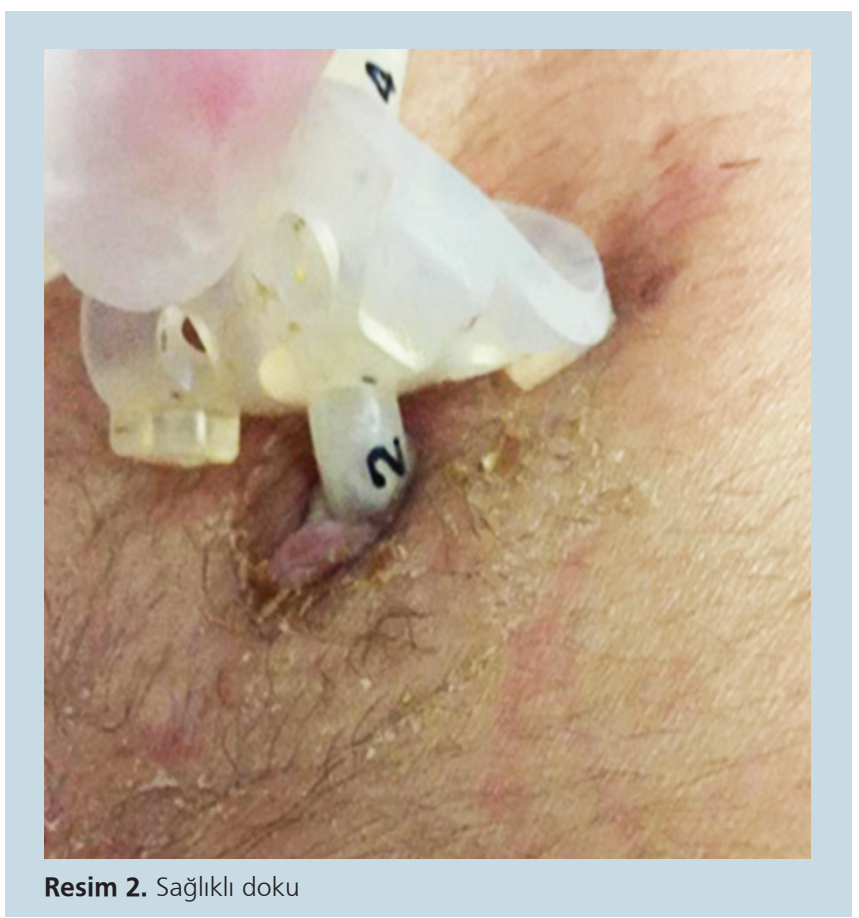


\%10 povidon iyot solüsyon ile silinip kuruması sağlandıktan sonra kapatılarak yapılmıştır. Bu dönemde hipergranülasyon dokusu gelişmemiştir. Palyatif bakım ünitesinde ise PEG tüpünün bakımı günlük distile su ile silinip kurulandıktan sonra açık bırakılarak yapılmıştır. Palyatif bakım ünitesinde onuncu günde olgumuzda hipergranülasyon dokusu gelişmiştir (Resim 1). Hipergranülasyon dokusu gelişince PEG tüpünün bakımı uzman görüşü alınarak, günlük \%10 povidon iyot solüsyonu ile silme, kurulama ve açık bırakma prosedürü ile tekrar yapılmaya başlanmıştır. Bakımın yedinci gününde hipergranülasyon dokusu küçülmeye başlamış ve on beşinci günde tamamen ortadan kalkmıştır (Resim 2).

Komplikasyonları önlemek ve komplikasyon geliştiğinde erken tedavisini yapmak hasta bakımına katılan sağlık perso-

\section{KAYNAKLAR}

1. Ukleja A, Gilbert K, Mogensen KM, et al. Standards for nutrition support: Adult hospitalized patients. Nutr Clin Pract 2018;33:906-20.

2. Gauderer M. Twenty years of percutaneous endoscopic gastrostomy: Origin and evolution of a concept and its expanded applications. Gastrointest Endosc 1980;50:879-83.

3. Friginal-Ruiz AB, Lucendo AJ. Percutaneous endoscopic gastrostomy A practical overview on its indications, placement conditions, management, and nursing care. Gastroenterol Nurs 2015;38:354-68.

4. Sobotka L. Klinik Nütrisyon Temelleri. Çev. ed. Gündoğdu RH. Ankara Bayt Yayın; 2017.

5. Azar AR, Rahnemaiazar AA, Naghshizadian R, Kurtz A, Farkas DT. Percutaneous endoscopic gastrostomy: Indications, technique, complications and management. World J Gastroenterol 2014;20:7739-51.

6. Heuschkel RB, Gottrand F, Devarajan K; European Society for Pediatric Gastroenterology, Hepatology, and Nutrition. ESPGHAN position paper on management of percutaneous endoscopic gastrostomy in children and adolescents. J Pediatr Gastroenterol Nutr 2015;60:131-41.

7. Simons S, Remington R. The percutaneous endoscopic gastrostomy tube: A nurse's guide to PEG tubes. Medsurg Nurs 2013;22:77-83. neli ve bakıcılara eğitim ve bilgi sağlamak doğru bakım için gereklidir. Her durumda erken komplikasyonları belirlemek ve tedavi etmek hastalar için güvenlik ve etkinlik sonuçlarını en üst seviyeye çıkaracaktır.

Sonuç olarak bizim olgumuzda olduğu gibi \%10 povidon iyot solüsyonunun hipergranülasyon dokusu tedavisinde etkili olduğunu düşünmekteyiz. Nütrisyon hemşirelerine ve PEG tüpü bakımı yapan tüm hemşirelere \%10 povidon iyot solüsyonu kullanarak PEG bakımı eğitimi verilmesinin granülasyon dokusu gelişimini azaltacağı kanısındayız. Hipergranülasyon doku tedavisi yapilırken uygun solüsyonun seçimi ve uygulama şekli konusunda talimatlar oluşturulmalıdır. Bu talimatların sağlıklı oluşturulması açısından güncel ve nitelikli araştırmalara gereksinim duyulmaktadır.

8. Warriner L, Spruce P. Managing overgranulation tissue around gastrostomy sites. Br J Nurs 2012;21:S14-6, S18, S20 passim.

9. Martin M, Kingan MJ. Percutaneous tubes and drains. J Wound Ostomy Continence Nurs 2018;45:543-4.

10. https://www.nursingtimes.net/clinical-archive/peg-tubes/peg-tubes-dealing-with-complications/5076347.article?)pdf. Erişim tarihi: 21.04.2019.

11. Roveron G, Antonini M, Barbierato M, et al. Clinical practice guidelines for the nursing management of percutaneous endoscopic gastrostomy and jejunostomy (PEG/PEJ) in adult patients. J Wound Ostomy Continence Nurs 2018;45:326-34.

12. McClave SA, DiBaise JK, Mullin EG, Martindale RG. ACG Clinical guideline. Nutrition therapy in the adult hospitalized patient. Am J Gastroenterol 2016;111:315-34. 